\title{
特集に寄せて
}

回路・実装設計技術委員会委員長 菊地 秀雄 *, 同副委員長 島㟢 睦**

\section{Introduction to the Special Edition}

Hideo KIKUCHI* and Mutsumi SHIMAZAKI**

* 群馬大学大学院理工学研究院知能機械創製部門組込みシステム研究室（† 373-0057 群馬県太田市本町 29 番 1 号)
**三菱電機株式会社設計システム技術センター（６61-8661＼cjkstart兵庫県尼崎市塚口本町 8-1-1）
*Mechanical Science and Technology, Gunma University (29-1, Hon-cho, Ota, Gunma 373-0057)
**Mitsubishi Electric Corporation Design Systems Engineering Center (8-1-1, Tsukaguchihon-cho, Amagasaki, Hyogo 661-8661)

「設計」とは何かという説明の 1 つとして, 中小機構（独 立行政法人 中小企業基盤整備機構）のデザイン支援ハンド ブックの中のデザインの基礎知識では, 商品開発プロセス の3つのモデルにおけるデザインの役割についての説明が あります。その 3 つのモデルとは, (1)プロダクトアウトに よる“製品開発”プロセス(2)マーケットインによる“商品 開発”プロセス(3)『問題解決のためのデザイン』プロセスで す。

本特集では，こうしたプロセスを意識した「システム設 計の体系図」(次項) のバラエティを含むシステム設計の豊 富な情報・知恵を集めるべく, 技術を生み出す広い知的生 産活動の枠組みの中でシステム設計が捉えられるよう，「21 世紀のシステム設計」と題して特集を組むことにしました。

第 1 に, 回路設計に関して, 伝送線路や LSI モデルや実 装ボードにおけるノイズ伝搬を把握する技術を解説しまし た。

第 2 に, 部品設計に関して, IoT における通信モジュー ル技術やパッケージ技術や DDR メモリ技術や $\mathrm{SiC}$ 技術や, バウンダリスキャン技術を解説しました。

第 3 に，基板の実装設計の技術を解説しました。

第 4 に, 製品設計に関して, 宇宙太陽光発電技術の一部 でもあるマイクロ波によるワイヤレス給電システムや, $\mathrm{EMC}$ 設計技術の進化, 近距離ワイヤレス通信技術, 小型モ ビリティ用モータ技術や組込みシステム技術, 自動車への ワイヤレス電力伝送技術を解説しました。

第 5 に, 設計ツールに関して, 電磁界／回路シミュレー ションを高度化するビジョン, 3 次元積層 IC 設計モデリン グ技術, CAD/CAM 融合ツール技術, 各シミュレーション ツールを使いこなす技術を解説しました。

これらの解説記事の情報が読者の方々のシステム設計に 有効な情報となることを期待するとともに，寄稿していた だいた執筆者の方々に厚く御礼を申し上げます。

\section{「システム設計の体系図」について}

回路・実装設計技術委員会における現在の研究題材は, デザイン・アーキテクチャーの革新を目的に，広域な範囲 での実装設計の多次元 (3D) 化と上流（フロントローディン グ）化に発展してきました。中でも設計環境・EDA (CAD/ CAE) と, その設計技術の関連性や協調・連携に関して, 知 見を共有し方向性を考える「システム設計研究会」（2017～) が発足しています。

現状認識として，2017 年時点での「システム設計」とは どんなことかを議論すると（後述）, 設計対象の違いにより メンバー間のイメージが異なり，それが「実装」における 「システム設計」であることが判り始めています。LSI 設計 者は, システム記述言語による論理回路とソフトウェアの 同時設計および最適化のことと思い, 基板やパッケージの 設計者は，チップ・パッケージ・ボードの実装上の協調し た設計作業をイメージしています。またセットメーカの回 路設計者は, 主にマイコン周辺の $\mathrm{H} / \mathrm{W}$ と組込み $\mathrm{S} / \mathrm{W}$ のバ ランス検討や，ボード間の接続と回路分割をすることを想 定している様です。

「システム設計」の定義は別の場へ委ねるとして, 本会で は「電子回路基板 (Electronic Circuit Board) の実装」の観点 における設計形態の最適化を考えていきます。設計と呼ば れる作業 ${ }^{* 1}$ と, その作業に要求される技術についての関係 を整理して，新たに確立された技術や用意されたツールを マッピングしながら，「システム設計」の将来あるべき姿, 若しくは今後に要求されるエリアを予想する試みです。

\section{○設計とその技術の体系化}

本会にて画いた設計の体系図（系統図）を図 1 に示しま す。JIEP の実装分野マップ，および講演大会のセッション

\footnotetext{
※1 設計とは, 研究・開発若しくは既存の特性（物性）情報を元に，製造の実 現とコストのバランスを図り，製品の機能（品質・信頼性・安全性）を作 りこむ作業 $\Rightarrow$ OUTPUT : 図面, 設計仕様書, とそのデー夕)
} 


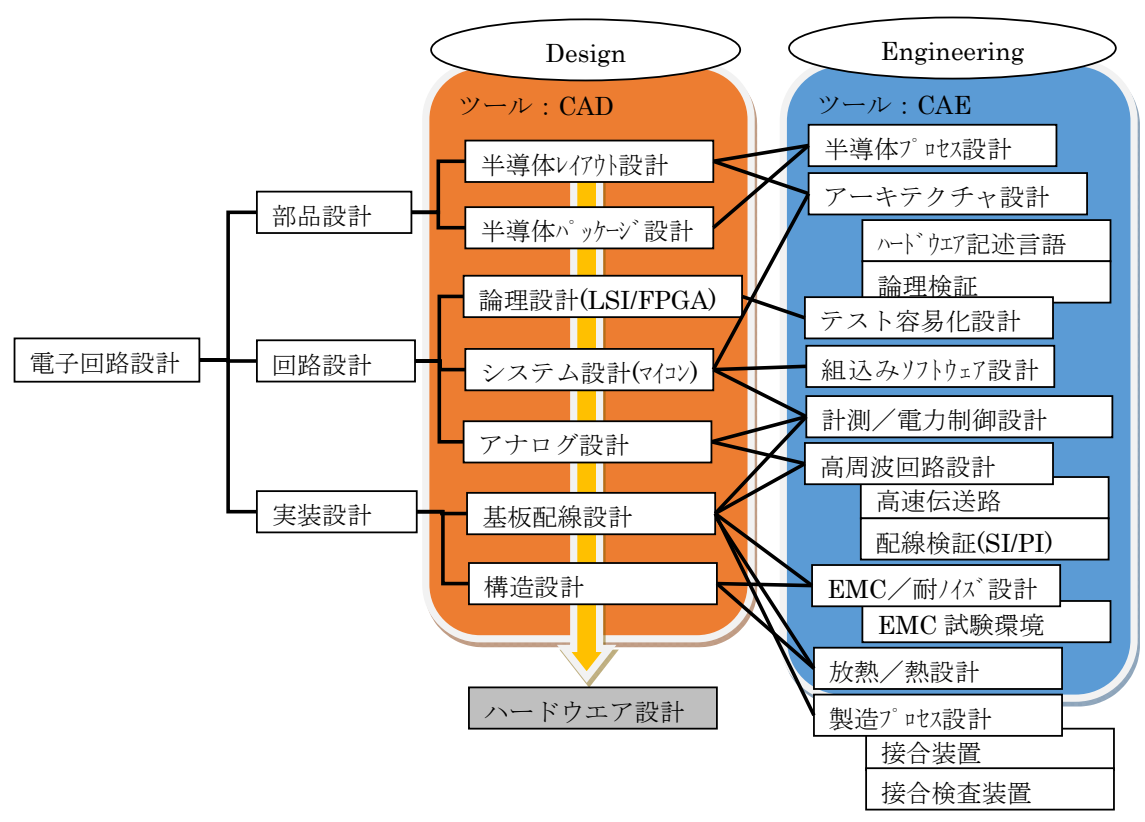

図 1. 電子回路基板（Electronic Circuit Board）における設計の体系図（系統図）

カテゴリ (キーワード) から「設計」の文字を持つ技術を 抽出し, 過去の研究会での発表内容に当てはまる分野の「設 計作業 (Design)」とその確立した「専門技術 (Engineering)」 の関係について，一目できる形へ整理したものです。この 図はまだ，関わる全ての設計者の合意を得ていませんの で, CAD 作業のフローなどの不確かな部分もありますが, 「システム設計」を考える上での議論のたたき台にして，精 度を上げていけるものと考えています。

\section{$\bigcirc 2017$ 年時点の「システム設計」}

本会メンバーの思う「システム設計」を以下に紹介しま す。「電子回路基板の実装」という条件下においても, 現時 点では各専門家のイメージが一つではなく, このテーマに 対するべクトルが異なることが判ります。違いの理解が, 新たな方向や創造の第一歩になるものと考え, 広く皆様か らのご意見をお願い申し上げます。

・プリント配線板設計会社 エンジニア

シングルボード設計では, 多くの場合，コネク夕経由で 別のボード信号が伝送されたり，メモリーモジュールなど として実装されたり，USB ケーブルで別のデバイスとつな がる事が多い。これら，外付けのボード，モジュール， ケーブル経由での別のデバイス全体の構成を「システム設 計」としてとらえている。

またパッケージ (インターポーザ) 設計におけるシステ ムとは, チップ／パッケージ/ボードの全体ととらえ, ド ライバーからレシーバまでの経路を含むものと考える。（別 のボードやモジュールまで伝達する場合はその全体）ここ では電気特性とコストのバランスを保つ必要があるため, 多くの情報とチップ設計者やボード設計者とのコミュニ ケーションを必要とする。いわゆる協調設計により, 物理 的レイアウト, 電気的特性, 熱的特性, 実装信頼性, トー
タルコストを実現している。

$$
\text { ・CAD メーカ/ベンダー マネージャ }
$$

最新の EDA は,「システムレベルマルチボード設計環境」 として世の中に出ている。ここでいうシステムとは, フレ キやコネクタ，またはケーブルで接続された複数のボード だったり，チップ／パッケージ/ボードという階層の違う ものをひとつの塊としてとらえている。また電気系のみな らず，筐体のメカデータもひとつの部品という扱いで,

基板 + 筐体 $=$ システム

として扱っている。また別のとらえ方に，回路ブロック間 をまたぐものをシステムとして表現する場合がある。物理 的にボードが 1 枚か複数かというより, 違う機能単位ごと を複数まとめるとシステムという考え方になる。

さらに上位の概念としては, 複合機などのように複雑な 電気部品, 稼働部品がある場合, 制御系含めてそのすべて をシステムと呼んでいる。自動車や工作機械ということで 考えた場合，モデルベースデザインという考え方となり， 工作機械では装置単体のみならず, 動力電源配線や容量, ガスや液の配管，工場における機器の搬入から配置，通信 線, センサーの取り付け位置などを含めて〔システム設計」 と位置付けている。

\section{・プリント配線板設計会社 マネージャ}

プリント配線板アートワーク（以下， A/W）設計者にとっ ての最終成果物は「 $\mathrm{A} / \mathrm{W}$ デー夕」であり, その要求は時代 と共に変化して，近年では最終製品における性能を予測し 満足させることが求められている。 $\mathrm{A} / \mathrm{W}$ は製品を構成する システムの一部であるが，単体ではなく全体を通して，時 には筐体などの構造物や回路の構成などにも関与しながら 製品の要求事項を満たすことが必要となってきている。

$\mathrm{A} / \mathrm{W}$ 設計者における「システム設計」とは，単に基板の 仕様だけでなくシステム全体を見据えシステムに合わせた 
（協調した）設計を行なうことといえる。現在の設計キー ワードは, SI/PI/EMC/熱/応力 であり，それぞれが関 連しているので CAD や各 CAE などのッールが同じデー夕 を共有できることが望まれる。「現象を理解する知識」と 「解決するためのノウハウ」を身につけること, 回路設計や 構造設計など他の設計者と折衝をすること, が「システム 設計」に必要なことと考える。

\section{・SI プロジェクトマネージャ}

一般的なシステム開発は, 要件定義, 基本設計（外部設 計), 詳細設計 (内部設計) などのフェーズからなる。基本 設計では, 要件定義フェーズの成果物である機能要件, 非 機能要件，制約条件にもとづいて，方式設計（アーキテク チャ設計）と機能設計（アプリケーション設計）を実施す る。このうち方式設計は, ハードウェア・ソフトウェアの 構造や実装方式を定める作業である。システムの構造およ び実装を表すアーキテクチヤのイメージとしては，ネット ワークの階層を定義した OSI (Open Systems Interconnection) 参照モデルがしばしば例にあげられる。

・セットメーカ/半導体メーカ エンジニア

$\mathrm{PC}$ のようなコモデイテイ製品の設計をセットメーカの立 場から考えると, キーとなる部品は既にあるものを利用す るので「部品設計」の部分はすっぽり抜けることになりま す。「回路設計」「実装設計」の部分では, 目的とする機 能・性能を実現することは当然ですが，製造性の考慮 (DFM)，テスト容易化 (DFT), デバッグしやすさ (DFD) と いった「DFx」を意識した設計が求められます。これも 「システム設計」の重要な項目です。

なお，コモディティ製品向けの汎用 IC を作る半導体メー カの立場では, 自社製品を広く使ってもらうために（完成 品としての）【システム(設計)」を意識します。キーコン ポーネント（CPUなどの半導体だけでなく，OSのような ソフトウェアも）のメーカが最終製品のコンセプトを発表 したり規格化するのはこのためです。部品メーカが自社製 品（部品）を載せるプラットフォームを（概略ですが）設 計します。また, インターフェイスの規格化・標準化, 周 辺デバイスに対する要求仕様設計も一部の半導体メーカが 主導し, 関連の部品メーカやセットメーカと協調して, 行 います。こういう「エコシステム」を作ることが, 半導体 メーカとしての「システム設計」の最終目標ではないかと 思います。

・システムインテグレーター

思い浮かぶ「システム設計」について述べると, システ ムとは，ハードウェア，ソフトウェアが混在している，あ る業務要件を満足するための物理的な手段であると考えま す。その設計とは, 受注, 要件定義, 概要設計, 詳細設 計, 製造, テスト, 納品, 保守までの一連の製品ライフサ イクルにおいて, 概要設計と詳細設計に相当します。特に 概要設計ではハードウェア，ソフトウェアを区別するわけ ではなく, 業務要件を満足するように抽象化された機能ブ ロック単位の組み合わせにより設計作業を行っています。
概要設計においてはハードウェアの方が，物理的な手段と してより抽象化されたように感じます。システムインテグ レーターにとって, ハードウェアはあまり重要視されず， 調達品の一つぐらいの扱いです。

\section{・大学（システム情報工学） 教員}

LSI 設計の立場からすると，「システム設計」と言えば, “ハード・ソフト協調設計 (hard/soft co-design)” というキー ワードがまず思い浮かびます。特に $\mathrm{SoC}$ (例えば， ARM コ ア＋専用回路といったLSI）の設計では，まずは，処理全 てをソフト（例えば c や Java，最近では python）で記述し， その中で，ハード化しないと性能が出ない部分を専用回路 で実現する（オフロードする）といった設計になっていま す。LSI 設計の立場からするとこのような設計が，今後， 実装設計とどのように䌘がるかに興味があります。

・セットメーカ マネージャ

量産までの工程で「システム設計」の位置づけ

\begin{tabular}{|c|c|c|c|c|c|c|}
\hline $\begin{array}{l}\text { 企画 } \\
ス テ フ ゚\end{array}$ & \multicolumn{5}{|c|}{ 設計ステップ } & $\begin{array}{l}\text { 生产設計 } \\
\text { ステップ }\end{array}$ \\
\hline $\begin{array}{l}\text { エレキ } \\
\text { 設計工程 }\end{array}$ & \multirow{3}{*}{$\frac{\text { システム }}{\text { 設計 }}$} & $\begin{array}{l}\text { エレキ } \\
\text { 設計 }\end{array}$ & 試作組立 & $\begin{array}{l}\text { エレキ } \\
\text { 評価 }\end{array}$ & \multirow{3}{*}{$\begin{array}{l}\text { システム/ } \\
\text { 総合評価 }\end{array}$} & \multirow{3}{*}{$\begin{array}{l}\text { 組立性 } \\
\text { 評価 }\end{array}$} \\
\hline $\begin{array}{l}\text { メカ } \\
\text { 設計工程 }\end{array}$ & & $\begin{array}{l}\text { メカ } \\
\text { 設計 }\end{array}$ & 試作組立 & $\begin{array}{l}\text { メカ } \\
\text { 評価 }\end{array}$ & & \\
\hline $\begin{array}{l}\text { ソフト } \\
\text { 設計工程 }\end{array}$ & & $\begin{array}{l}\text { ソフト } \\
\text { 設計 }\end{array}$ & $\begin{array}{l}\text { プログラ } \\
\text { ミング }\end{array}$ & $\begin{array}{l}\text { ソフト } \\
\text { 評価 }\end{array}$ & & \\
\hline
\end{tabular}

標準設計工程中の「システム設計」の要件

\begin{tabular}{|c|c|}
\hline 企画のアウトプット & \\
\hline$\downarrow$ & \\
\hline 要求仕様分析 & 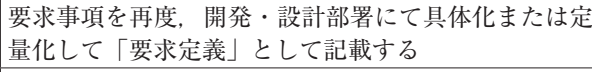 \\
\hline$\downarrow$ & \\
\hline 要求定義 & \\
\hline$\downarrow$ & \\
\hline 機能展開 & $\begin{array}{l}\text { 実現性, 実現手段, 検証手段を考慮しながら階層的に } \\
\text { 「要求定義」を機能的に展開（機能ブロック化）する }\end{array}$ \\
\hline$\downarrow$ & \\
\hline 機能 /規格要件 & \\
\hline$\downarrow$ & \\
\hline 品質計画 & 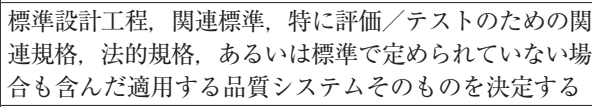 \\
\hline$\downarrow$ & \\
\hline 設計計画 & $\begin{array}{l}\text { 「設計計画書」の元となるものであり，根拠，決定基 準, 決定プロセスなどを含めて記載することが重要で } \\
\text { ある }\end{array}$ \\
\hline$\downarrow$ & \\
\hline 製品規格 & 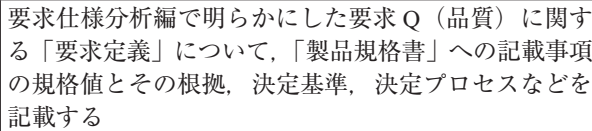 \\
\hline
\end{tabular}

(2018.5.30- 受理)

菊地秀雄（きくち ひでお）

著者紹介

群馬大学大学院 理工学研究院 知能機械創製部門 組込みシステム研 究室

1974 年 NEC 入社

2011 年トッパン NEC サーキットソリューションズ定年退職

島嵜 睦（しまざき むつみ）

三菱電機(侏設計システム技術センター

工学博士 